\title{
Pengaruh Metode Pembelajaran Struktural Analitik Sitentik Terhadap Kemampuan Menulis Permulaan di Sekolah Dasar
}

\author{
Yunita Sari ${ }^{1}$, Ratri Dyah Luvita ${ }^{1}$, Andarini Permata Cahyaningtyas ${ }^{1}$, Vina Iasha ${ }^{2}$ Bramianto Setiawan $^{3}$ \\ Program Studi Pendidikan Guru Sekolah Dasar, Universitas Islam Sultan Agung Semarang, Indonesia ${ }^{1}$ \\ Program Studi Pascasarjana Pendidikan Dasar, Universitas Negeri Jakarta, Indonesia ${ }^{2}$ \\ Program Studi Pendidikan Guru Sekolah Dasar, Universitas PGRI Adi Buana, Indonesia ${ }^{3}$ \\ E-mail : yunitasari@unissula.ac.id ${ }^{1}$ ratridyahluvita@ std.unissula.ac.id ${ }^{1}$ andarinipermata@ unissula.ac.id $^{1}$
} vina.iasha@gmail.com ${ }^{2}$ - sbramianto@unipasby.ac.id ${ }^{3}$

\begin{abstract}
Abstrak
Penelitian ini bertujuan untuk mengetahui pengaruh model pembelajaran Struktural Analitik Sintetik terhadap kemampuan menulis permulaan siswa kelas 1 SD Negeri Sembungharjo 02. Metode yang digunakan dalam penelitian adalah metode Quasi Eksperimen dengan Nonequivalent Control Group Design. Data yang diperoleh dianalisis menggunakan 2 buah uji hipotesis yakni, uji t berpasangan, dan uji beda rata-rata kemampuan menulis permulaan. Dari analisis data diperoleh bahwa uji hipotesis kemampuan menulis permulaan berupa yang pertama uji t berpasangan pada kelas eksperimen diperoleh $t_{\text {hitung }}-15,45$ dan $t_{\text {tabel }} 2,0518$ dengan kriteria $t_{\text {hitung }} \leq-t_{\text {tabel }}$ maka $\mathrm{H}_{\mathrm{o}}$ diterima. Sedangkan untuk kemampuan menulis permulaan di kelas kontrol diperoleh $t_{\text {hitung }}-4,16$ dan dan $t_{\text {tabel }}$ 2,0518 dengan kriteria $t_{\text {hitung }} \leq-t_{\text {tabel }}$ maka $\mathrm{H}_{\mathrm{o}}$ diterima. Uji $\mathrm{t}$ dua pihak berdasarkan perhitungan uji kesamaan dua rata-rata kemampuan menulis permulaan diperoleh $t_{\text {hitung }} 3.065$ dan $t_{\text {tabel }}$ 2.0211. dengan kriteria pengujian yang berlaku adalah Ho diterima jika $-t_{\text {tabel }} \leq t_{\text {hitung }} \leq t_{\text {tabel }}$ karena perolehan nilai t hitung 3.065 berada pada area penolakan Ho yaitu $-2.0211 \leq 3.065 \geq 2.0211$ maka $\mathrm{H}_{\mathrm{o}}$ ditolak yang dapat disimpulkan ada pengaruh metode Struktural Analitik Sitentik terhadap kemampuan menulis permulaan.
\end{abstract}

Kata kunci: model pembelajaran, Struktural Analitik Sintetik (SAS), kemampuan menulis permulaan

\section{Abstract}

This study aimed to determine the effect of synthetic analytical structural learning model on the initial writing ability of grade 1 students at SD Negeri Sembungharjo 02. The method that was used in this research was the Quasi Experiment method with Nonequivalent Control Group Design. The data obtained were analyzed using 2 hypothesis tests, namely, paired t test, and mean difference test of pre-writing skills. From the data analysis, it was found that the initial writing ability hypothesis test in the form of the first paired t test in the experimental class obtained $t_{\text {count }}$ 15.45 and $t_{\text {table }} 2.0518$ with the criteria $t_{\text {count }} \leq-t_{\text {table }}$, so $H_{o}$ was accepted. Whereas for the pre-writing ability in the control class obtained $t_{\text {count }}-4.16$ and and $t_{\text {table }} 2.0518$ with the criteria $t_{\text {count }} \leq-t_{\text {table, }}$ so $H_{o}$ is accepted. The twoparty $t$ test based on the calculation of the two-sided similarity test on the average of the initial writing ability obtained $t_{\text {count }} 3.065$ and $t_{\text {table }} 2.0211$. with the applicable test criteria, $H_{o}$ is accepted if $-t_{\text {table }} \leq t_{\text {count }} \leq t_{\text {table }}$ because the acquisition of the $t$ value of 3.065 is in the area of $H_{o}$ 's rejection, which is $-2.0211 \leq 3.065 \geq 2.0211$ then $H_{o}$ is rejected and which can be concluded that there is an effect of structural analytical structural methods on the ability write a start.

Keyword: learning model, struktural analitik sintetik (SAS), pre-writing skills

Copyright (c) 2020 Yunita Sari, Ratri Dyah Luvita, Andarini Permata Cahyaningtyas, Vina Iasha, Bramianto Setiawan

$\bowtie$ Corresponding author

Address : Jl. Kaligawe Raya No.KM. 4, Semarang

Email : yunitasari@unissula.ac.id

Phone : 081391879252

ISSN 2580-3735 (Media Cetak)

ISSN 2580-1147 (Media Online)

DOI: https://doi.org/10.31004/basicedu.v4i4.515 
1125 Pengaruh Metode Pembelajaran Struktural Analitik Sitentik Terhadap Kemampuan Menulis Permulaan di Sekolah Dasar - Yunita Sari, Ratri Dyah Luvita, Andarini Permata Cahyaningtyas, Vina Iasha, Bramianto Setiawan

DOI: https://doi.org/10.31004/basicedu.v4i4.515

\section{PENDAHULUAN}

Ada empat keterampilan yang harus dikuasai dalam belajar bahasa yakni berbicara, menyimak, membaca, dan menulis. Keempat keterampilan berbahasa tersebut saling berkaitan. Kegunaan kemampuan menulis permulaan bagi siswa adalah untuk menjiplak, menebalkan, mencontoh, melengkapi, dan menyalin. Tanpa memiliki kemampuan menulis permulaan siswa akan mengalami banyak kesulitan dalam menyelesaikan tugas belajarnya. Siswa yang mengalami kesulitan belajar menulis permulaan harus memperoleh perhatian yang cukup, karena banyak siswa yang belum dapat mencapai tujuan yang diharapkan. Hal ini menunjukkan bahwa siswa belum tuntas dalam pembelajaran membaca dan menulis permulaan (Masrup, 2012). Kemampuan dalam menulis permulaan hampir sama dengan kemampuan membaca permulaan. Saat tingkat permulaan atau tingkat sekolah dasar, pembelajaran kemampuan menulis lebih diutamakan pada kemampuan yang mempunyai sifat mekanik. Siswa kelas 1 dilatih untuk mempunyai kemampuan menulis (mirip dengan kemampuan menggambar) lambang tulis yang apabila dirangkai dalam struktur kalimat menjadi bermakna. Kemudian, melalui kemampuan dasar tersebut, secara perlahan siswa diarahan kepada kemampuan menuangkan ide atau pikiran dan perasaan ke bentuk bahasa tulis melalui bentuk lambang-lambang. Selanjutnya, siswa menulis yang sudah dikuasai. Seperti itulah kemampuan menulis yang sebenarnya (Widyaningrum, H. K., Hasanudin, 2019). Apabila siswa pada usia sekolah permulaan tidak segera memiliki kemampuan membaca menulis, siswa akan mengalami banyak kesulitan dalam mempelajari berbagai bidang studi pada kelas berikutnya. Keterampilan membaca sangat penting untuk kehidupan sehari-hari dan untuk sukses di sekolah dan tempat kerja. Akibatnya, banyak pemuda dengan tingkat kemahiran membaca yang lebih rendah lebih banyak terkena pengangguran, kemiskinan dan kejahatan (Goux, D., Gurgand, M., and Maurin, 2017). Selain itu, instruktur membaca merupakan cara yang valid dan dapat diandalkan untuk mengevaluasi persepsi diri dan sikap terhadap membaca. Sikap terhadap membaca memiliki salah satu peran penting dalam pengembangan dan penerapannya kemampuan membaca yang stabil Mihandoost (Goux, D., Gurgand, M., and Maurin, 2017). Sedangkan menurut Tarigan, menulis merupakan suatu ketrampilan berbahasa yang dipergunakan untuk berkomunikasi secara tidak langsung, tidak secara tatap muka dengan orang lain (Tarigan, 2008). Menulis merupakan suatu kegiatan yang produktif dan ekspresif. Keterampilan menulis ini tidak datang secara otomatis, tetapi harus melalui latihan dan praktik yang banyak dan teratur. Selanjutnya menurut Temur, menulis menjadi bagian dari ketrampilan komunikasi dan dari waktu ke waktu datang untuk menjadi bagian dari kegiatan pendidikan (Temur, 2011). Melalui tulisan, seseorang akan dapat mengungkapkan gagasan maupun perasaannya kepada orang lain melalui lambang-lambang grafis, tanpa harus bertemu langsung dengan orang lain tersebut. Orang akan mengetahui gagasan atau perasaan orang lain lewat tulisan jika orang itu memahami bahasa dan 
1126 Pengaruh Metode Pembelajaran Struktural Analitik Sitentik Terhadap Kemampuan Menulis Permulaan di Sekolah Dasar - Yunita Sari, Ratri Dyah Luvita, Andarini Permata Cahyaningtyas, Vina Iasha, Bramianto Setiawan

DOI: https://doi.org/10.31004/basicedu.v4i4.515

lambang grafis yang digunakan. Zulela MS juga mengungkapkan bahwa keterampilan menulis sebagai salah satu aspek keterampilan berbahasa merupakan tahap akhir yang dikuasai siswa, karena siswa dapat menulis dengan baik apabila serangkaian tahapan aspek keterampilan berbahasa telah dikuasai siswa (MS, 2014). Sedangkan Suparno dkk menjelaskan bahwa menulis adalah suatu kegiatan penyampaian pesan (komunikasi) dengan menggunakan bahasa tulis sebagai alat atau mediana (Suparno \& Yunus, 2009). Pesan adalah isi atau muatan yang terkandung dalam suatu tulisan.

Menulis permulaan menjadi salah satu materi pengajaran menulis di kelas I dan II karena dalam menulis permulaan lebih memfokuskan pengenalan penulisan huruf dan kedudukan atau fungsinya di dalam suatu kata dan kalimat. Pada tingkat permulaan, pembelajaran menulis lebih diorentasikan pada kemampuan yang bersifat mekanik. Anak dilatih untuk menuliskan lambanglambang tulisan yang jika dirangkai dapat menjadi bermakna. Selanjutnya,secara perlahan-lahan anak diarahkan pada kemampuan menuangkan gagasan, ide, pikiran, perasaan ke dalam bentuk bahasa tulis melalui lambang-lambang tulis yang telah dikuasainya.

Menurut Dewi Mustikowati, dkk bahwa menulis permulaan di kelas rendah siswa sekolah dasar tujuannya adalah agar siswa memahami cara menulis permulaan dengan ejaan yang benar dan mengkomunikasikan ide/pesan secara tertulis, materi pelajaran menulis permulaan di kelas rendah sekolah dasar disajikan secara bertahap dengan menggunakan pendekatan huruf, suku kata, kata-kata atau kalimat (Mustikowati, 2016).

Kemampuan menulis permulaan sesungguhnya tidak dapat dipisahkan dengan kemampuan membaca permulaan. Pada pembelajarannya siswa diajarkan untuk bisa menuliskan lambang-lambang tulis yangkemudian dirangkaikan menjadi sebuah struktur lambanglambang maka bisa menjadi sebuah yang berarti . Dengan perlahan-lahan anak akan dibimbing pada sebuah kemampuan menuangkan sebuah pendapat, pikiran, perasanan yang dibuat dalam wujud bahasa tulis menggunakan lambang-lambang yang telah dimilikinya. Inilah yang disebut dengan kemampuan menulis yang sebetulnya.

Akan tetapi pada kenyataanya yang ada di lapangan masih banyak permasalahan yang merujuk pada ketidakmampuan siswa menulis , ditemukan beberapa siswa yang pandai menulis. Sebagaimana yang terjadi kelas 1 SDN Sembungharjo 02, berdasarkan hasil wawancara dengan Ibu Eka selaku wali kelas 1 SDN Sembungharjo 02 kemampuan menulis di kelas 1 SDN Sembungharjo 02 ini masih kurang. Kurangnya kemampuan menulis ini bisa dilihat dari kegiatan pembelajaran saat di kelas. Ketika siswa di minta untuk menulis sebuah kata siswa mengalami kesusahan dalam menulis bahkan masih ada siswa yang belum hafal huruf a-z.

Permasalahan ini timbul dengan latar belakang yang bermacam-macam. Contohnya berasal dari lingkungan keluarga karena orang tuanya yang sibuk bekerja sehingga di rumah tidak ada waktu luang untuk mengajarkan anak menulis, serta kurangnya minat yang dimiliki anak 
1127 Pengaruh Metode Pembelajaran Struktural Analitik Sitentik Terhadap Kemampuan Menulis Permulaan di Sekolah Dasar - Yunita Sari, Ratri Dyah Luvita, Andarini Permata Cahyaningtyas, Vina Iasha, Bramianto Setiawan

DOI: https://doi.org/10.31004/basicedu.v4i4.515

dikarenakan siswa malas atau karena mereka masih suka bermain. Dari 28 siswa terdapat 7 siswa yang belum lancar menulis. Kesalahan dalam penulisan huruf dan kurang tepat dalam penulisan kata. Untuk 21 siswa lainnya sudah bisa menulis tetapi masih perlu ditingkatkan agar lebih baik lagi. Dengan permasalahan tersebut berpengaruh dengan nilai ulangan siswa. Pada saat siswa menjawab soal ada beberapa siswa kurang tepat dalam mengerjakannya yaitu tulisan siswa tidak dapat dibaca karena siswa asal menuliskan jawaban yang tidak sesuai. Dari permasalahan tersebut terlihat jelas bahwa kemampuan menulis permulaan siswa perlu ditingkatkan lagi. Solusi yang dapat dilaksanakan yaitu perlu ada bimbingan bagi siswa agar bisa belajar menulis secara optimal.

Guru mempunyai peranan penting dalam membimbing anak membaca dan menulis. Beberapa metode yang bisa diterapkan diantaranya metode membaca sadar, metode fonik, metode suku kata, metode alfabetik, dan metode SAS. Guru dituntut untuk bisa menciptakan pembelajaran yang menarik, jika guru berhasil membuat pembelajaran yang mengesankan siswa juga akan lebih tertarik mengikuti pembelajaran. Selain itu untuk kelas rendah guru disarankan dapat menggunakan media saat pembelajaran hal itulah yang juga dapat menarik minat siswa.

Guru dapat menggunakan metode Struktural Analitik Sitentik (SAS) pada saat pembelajaran untuk memecahkan permasalahan tersebut. Metode SAS adalah pembelajaran yang diawali dengan pengenalan struktur kalimat kemudian, kalimat diuraikan ke dalam satuan-satuan bahasa yang lebih kecil yang disebut kata (Hartati \& Y, 2015).

Proses penganalisisan atau penguraian ini terus berlanjut hingga pada wujud satuan bahasa terkecil yang tidak bisa diuraikan lagi, yakni huruf-huruf. Selanjutnya disintesiskan kembali menjadi kalimat. Metode SAS mempunyai langkah-langkah analisis-sintesis yang dapat membuat siswa cepat terampil dalam menulis, dapat mendukung siswa memiliki landasan berpikir analisis, sintesis dan inkuiri (menemukan sendiri). Materi yang diberikan kepada siswa harus berdasarkan pengalaman siswa dan bermakna bagi siswa. Serta setiap landasan pada metode SAS memiliki manfaat bagi siswa. Diantaranya landasan strukturalisme, landasan psikologi gestalt, landasan pedagogis, dan landasan linguistik.

Berdasarkan permasalahan yang terjadi maka perlu diadakan penelitian untuk mengetahui pengaruh metode pembelajaran Struktural Analitik Sitentik terhadap kemampuan menulis permulaan pada pembelajaran tematik siswa kelas 1 SD Negeri Sembungharjo 02.

Adapun tujuan yang ingin dicapai dengan diadakan penelitian ini adalah untuk mengetahui pengaruh model pembelajaran Struktural Analitik Sitentik (SAS) terhadap kemampuan menulis permulaan siswa kelas 1 SD N Sembungharjo 02.

\section{METODE}

Penelitian ini menggunakan metode quasi eksperimen design bentuk desain penelitian yang digunakan adalah nonequivalent control group design. Populasi dalam penelitian ini adalah 
1128 Pengaruh Metode Pembelajaran Struktural Analitik Sitentik Terhadap Kemampuan Menulis Permulaan di Sekolah Dasar - Yunita Sari, Ratri Dyah Luvita, Andarini Permata Cahyaningtyas, Vina Iasha, Bramianto Setiawan

DOI: https://doi.org/10.31004/basicedu.v4i4.515

seluruh siswa kelas 1 SDN Sembungharjo 02 yang berjumlah 56 siswa yang terdiri dari siswa laki-laki sebanyak 26 siswa daan siswa perempuan sebanyak 30 siswa. Teknik pengumpulan data adalah teknik tes unjuk kerja. Teknik analsis data awal meliputi uji normalitas,homogenitas dan kesamaaan rata-rata, sedangkan analisis data akhir meliputi uji normalitas, uji homogenitas dan uji hipotesis ( uji t berpasangan dan uji t beda ratarata).

\section{HASIL DAN PEMBAHASAN}

Penelitian ini dilakukan pada dua kelas yaitu satu kelas eksperimen yang mendapat pembelajaran dengan model Struktural Analitik Sitentik dan satu kelas kontrol yang mendapat pembelajaran model konvensional. Dari penelitian yang telah dilakukan diperoleh hasil

Tabel 1. Data Pretes kemampuan menulis

\begin{tabular}{|l|l|r|r|}
\hline \multirow{2}{*}{ No } & \multirow{2}{*}{ Kriteria data } & \multicolumn{2}{|c|}{ Data awal siswa } \\
\cline { 3 - 4 } & & Eksperimen & \multicolumn{1}{c|}{ Kontrol } \\
\hline 1. & Jumlah siswa & 28 & 28 \\
\hline 2. & Skor rata-rata & 67,82 & 68,10 \\
\hline 3. & Simpangan baku & 13,562 & 13,127 \\
\hline 4. & Skor minimal & 40 & 50 \\
\hline 5. & Skor maksimal & 90 & 90 \\
\hline
\end{tabular}

Pengolahan data awal menggunakan Microsoft Excel .berdasarkan data yang telah diperoleh menunjukkan bahwa kelas eksperimen yang berjumlah 28 diperoleh skor rata-rata 67,82 ; simpangan baku 13,562; skor minimal 40; skor maksimal 90. Sedangkan untuk kelas kontrol dengan jumlah siswa sebanyak 28 diperoleh skor rata-rata 68,40 ; simpangan baku 13,127 ; skor minimal 50; skor maksimal 90.
Tabel 2. Data Posttes kemampuan menulis

\begin{tabular}{|l|l|r|r|}
\hline \multirow{2}{*}{ No } & \multirow{2}{*}{ Kriteria data } & \multicolumn{2}{|c|}{ Data akhir siswa } \\
\cline { 3 - 4 } & & Eksperimen & \multicolumn{1}{c|}{ Kontrol } \\
\hline 1. & Jumlah siswa & 28 & 28 \\
\hline 2. & Skor rata-rata & 81,42 & 71,89 \\
\hline 3. & Simpangan baku & 9,700 & 13,295 \\
\hline 4. & Skor minimal & 63 & 47 \\
\hline 5. & Skor maksimal & 100 & 97 \\
\hline
\end{tabular}

Pengolahan data akhir menggunakan Microsoft Excel .berdasarkan data yang telah diperoleh menunjukkan bahwa kelas eksperimen yang berjumlah 28 diperoleh skor rata-rata 81,42 ; simpangan baku 9,700; skor minimal 63; skor maksimal 100. Sedangkan untuk kelas kontrol dengan jumlah siswa sebanyak 28 diperoleh skor rata-rata 71,89 ; simpangan baku 13,295 ; skor minimal 47; skor maksimal 97.

\section{Analisis data awal}

Uji normalitas digunakan untuk mengetahui kemampuan awal pada kelas eksperimen dan kontrol berdistribusi normal atau tidak. Pada penelitian ini uji normalitas data dilakukan dengan menggunakan uji liliefors seperti yang terpapar dalam tabel di bawah ini.

Tabel 3. Uji Normalitas Pretes Kemampuan Menulis

\begin{tabular}{|c|l|c|c|}
\hline \multirow{2}{*}{ No } & \multirow{2}{*}{ Kriteria data } & \multicolumn{2}{|c|}{ Uji normalitas } \\
\cline { 3 - 4 } & & Eksperimen & Kontrol \\
\hline 1. & $\begin{array}{l}\text { Jumlah } \\
\text { siswa }\end{array}$ & 28 & 28 \\
\hline 2. & $\begin{array}{l}\text { Skor rata- } \\
\text { rata }\end{array}$ & 67,82 & 68,10 \\
\hline 3. & $\begin{array}{l}\text { Simpangan } \\
\text { baku }\end{array}$ & 13,56207559 & 13,12712568 \\
\hline
\end{tabular}


1129 Pengaruh Metode Pembelajaran Struktural Analitik Sitentik Terhadap Kemampuan Menulis Permulaan di Sekolah Dasar - Yunita Sari, Ratri Dyah Luvita, Andarini Permata Cahyaningtyas, Vina Iasha, Bramianto Setiawan

DOI: https://doi.org/10.31004/basicedu.v4i4.515

\begin{tabular}{|c|l|c|c|}
\hline 4. & Lmaks & 0,084158957 & 0,124431714 \\
\hline 5. & Ltabel (n-1) & 0,17051078 & 0,17051078 \\
\hline
\end{tabular}

Pengujian normalitas ini dilakukan dengan menggunakan Microsoft Excel. Berdasarkan perhitungan uji normalitas Liliefors, pada kelas eksperimen yang berjumlah 28 siswa diperoleh nilai rata-rata 67,82 ; simpangan baku 13,56207559 dan taraf signifikan 5\% diperoleh Lmaks sebesar 0,084158957 dan Ltabel liliefors sebesar 0,17051078. Kriteria ujinya yaitu Lmaks < Ltabel maka data berdistribusi normal, maka diterima karena $0,084158957<0,17051078$.

Sedangkan untuk kelas kontrol yang berjumlah 28 siswa diperoleh nilai rata-rata 68,10 ; simpangan baku 13,12712568; dan taraf signifikan 5\%. Diperoleh Lmaks 0,124431714 dan Ltabel liliefors sebesar 0,17051078 . Kriteria ujinya yaitu Lmaks < Ltabel maka data berdistribusi normal, maka diterima karena 0,124431714 lebih kecil dari 0,17051078. Maka dapat disimpulkan bahwa kemampuan awal siswa kelas kontrol normal.

Untuk mengetahui homogenitas dari kelas eksperimen dan kontrol telah layak dijadikan sampel penelitian, berikut adalah hasil uji homogenitas seperti yang terpapar dalam tabel di bawah ini.

Tabel 4. Uji Homogenitas Pretes Kemampuan Menulis

\begin{tabular}{|c|l|c|c|}
\hline \multirow{2}{*}{ No } & \multicolumn{1}{|c|}{$\begin{array}{c}\text { Kriteria } \\
\text { data }\end{array}$} & \multicolumn{2}{|c|}{ Uji normalitas } \\
\cline { 3 - 4 } 1. & $\begin{array}{l}\text { Jumlah } \\
\text { siswa }\end{array}$ & 28 & Eksperimen \\
\hline 2. & $\begin{array}{l}\text { Skor rata- } \\
\text { rata }\end{array}$ & 67,82 & 68,10 \\
\hline 3. & Simpangan & 13,56207559 & 13,12712568 \\
\hline
\end{tabular}

\begin{tabular}{|c|l|l|l|}
\hline & baku & & \\
\hline 4. & Varians & 183,87 & 172,13 \\
\hline 5. & Fhitung & \multicolumn{2}{|c|}{1,06} \\
\hline 6. & Ftabel & \multicolumn{2}{|c|}{1,91} \\
\hline
\end{tabular}

Berdasarkan perhitungan uji homogenitas dua varians, diperoleh data pada kelas eksperimen yang berjumlah 28 siswa mempunyai rata-rata sebesar 67,82; simpangan baku sebesar 13,56207559 Sedangkan pada kelas kontrol yang berjumlah 28 siswa diperoleh rata-rata 68,10; simpangan baku 13,12712568; varian terbesar adalah dan varian terkecil. Diperoleh fhitung sebesar 1,06 dan ftabel 1,91 dan tarif signifikan $5 \%$. Kriteria ujinya jika fhitung < ftabel maka Ho diterima (varian homogen) maka diterima. Karena 1,06 lebih kecil dari 1,91, maka dapat disimpulkan bahwa data kemampuan awal kelas eksperimen dan kelas kontrol dapat diartikan bahwa tidak ada perbedaan varians antara kedua kelas.

Uji kesamaan rata-rata data awal siswa digunakan untuk membandingkan dan membuktikan bahwa kedua kelas yang akan digunakan yaitu kelas eksperimen dan kelas kontrol dalam penelitian ini tidak mempunyai perbedaan keadaan awal. Pengujian kesamaan dua rata-rata dalam penelitian ini menggunakan uji $\mathrm{t}$ dua pihak. Berikut ini merupakan hasil penghitungan yang tersedia dalam tabel di bawah ini.

Tabel 5. Uji Kesamaan Dua Rata-Rata Pretes Kemampuan Menulis

\begin{tabular}{|c|c|c|c|}
\hline No & \multirow{2}{*}{$\begin{array}{c}\text { Kriteria } \\
\text { data }\end{array}$} & \multicolumn{2}{|c|}{ Uji normalitas } \\
\cline { 3 - 4 } & Eksperimen & Control \\
\hline 1. & $\begin{array}{l}\text { Jumlah } \\
\text { siswa }\end{array}$ & 28 & 28 \\
\hline
\end{tabular}


1130 Pengaruh Metode Pembelajaran Struktural Analitik Sitentik Terhadap Kemampuan Menulis Permulaan di Sekolah Dasar - Yunita Sari, Ratri Dyah Luvita, Andarini Permata Cahyaningtyas, Vina Iasha, Bramianto Setiawan

DOI: https://doi.org/10.31004/basicedu.v4i4.515

\begin{tabular}{|c|l|c|c|}
\hline 2. & $\begin{array}{l}\text { Skor rata- } \\
\text { rata }\end{array}$ & 67,82 & 68,10 \\
\hline 3. & $\begin{array}{l}\text { Simpangan } \\
\text { baku }\end{array}$ & 13,56207559 & 13,12712568 \\
\hline 4. & Varians & 183,87 & 172,13 \\
\hline 5. & Sgabungan & \multicolumn{2}{|c|}{13,341} \\
\hline 6. & T hitung & \multicolumn{2}{|c|}{$-0,078$} \\
\hline 7. & T table & \multicolumn{2}{|c|}{2,0211} \\
\hline
\end{tabular}

Berdasarkan perhitungan uji kesamaan dua rata-rata, diperoleh data pada kelas eksperimen yang berjumlah 28 siswa mempunyai rata-rata sebesar 67,82; simpangan baku sebesar 13,56207559. Sedangkan pada kelas kontrol yang berjumlah 28 siswa diperoleh rata-rata 68,10 ; simpangan baku 13,12712568. Diperoleh T hitung sebesar -0,078 dan $\mathrm{T}$ tabel 2,0211 dengan keputusan $-\mathrm{t}$ tabel $\leq \mathrm{t}$ hitung $\leq \mathrm{t}$ tabel maka Ho diterima dengan tarif signifikan 5\%. Maka dapat disimpulkan bahwa data kemampuan awal kelas eksperimen dan kelas kontrol dapat diartikan bahwa tidak ada perbedaan kemampuan awal antara kedua kelas.

\section{Uji Normalitas Data Akhir}

Uji normalitas digunakan untuk mengetahui data nilai hasil tes kemampuan membaca dan menulis pada kelas eksperimen dan kontrol berdistribusi normal atau tidak. Pada penelitian ini uji normalitas data dilakukan dengan menggunakan uji liliefors.

Tabel 6 Uji Normalitas Postes Kemampuan Menulis

\begin{tabular}{|c|c|c|c|}
\hline \multirow{2}{*}{ No } & \multirow{2}{*}{$\begin{array}{c}\text { Kriteria } \\
\text { data }\end{array}$} & \multicolumn{2}{|c|}{ Uji normalitas } \\
\cline { 3 - 4 } 1. & Jumlah & Eksperimen & Control \\
\hline siswa & 28 & 28 \\
\hline
\end{tabular}

\begin{tabular}{|c|l|c|c|}
\hline 2. & $\begin{array}{l}\text { Skor rata- } \\
\text { rata }\end{array}$ & 81,42 & 71,89 \\
\hline 3. & $\begin{array}{l}\text { Simpangan } \\
\text { baku }\end{array}$ & 9,700815435 & 13,29533275 \\
\hline 4. & Lmaks & 0,079964856 & 0,157703628 \\
\hline 5. & $\begin{array}{l}\text { Ltabel (n- } \\
\text { 1) }\end{array}$ & 0,17051078 & 0,17051078 \\
\hline
\end{tabular}

Pengujian normalitas ini dilakukan dengan menggunakan Microsoft Excel. Berdasarkan perhitungan uji normalitas liliefors, pada kelas eksperimen yang berjumlah 28 siswa diperoleh nilai rata-rata 81,42 ; simpangan baku 9,700815435 dan taraf signifikan 5\% diperoleh Lmaks sebesar 0,079964856 dan Ltabel liliefors sebesar 0,17051078. Kriteria ujinya yaitu Lmaks < Ltabel maka data berirdistribusi normal, maka diterima karena $0,079964856<0,17051078$.

Sedangkan untuk kelas kontrol yang berjumlah 28 siswa diperoleh nilai rata-rata 71,89; simpangan baku 13,29533275; dan taraf signifikan 5\%. Diperoleh Lmaks 0,157703628 dan Ltabel liliefors sebesar 0,17051078 . Kriteria ujinya yaitu Lmaks < Ltabel maka data berdistribusi normal, maka diterima karena 0,157703628 lebih kecil dari 0,17051078. Maka dapat disimpulkan bahwa kemampuan awal siswa kelas kontrol normal.

Uji homogenitas data akhir untuk mengetahui hasil homogenitas dari kelas eksperimen dankontrol, berikut adalah paparannya.

Tabel 7 Uji Homogenitas Pretes Kemampuan Menulis

\begin{tabular}{|c|l|c|c|}
\hline No & \multirow{2}{*}{$\begin{array}{c}\text { Kriteria } \\
\text { data }\end{array}$} & \multicolumn{2}{|c|}{ Uji normalitas } \\
\cline { 3 - 4 } 1. & $\begin{array}{l}\text { Jumlah } \\
\text { siswa }\end{array}$ & 28 & 28 \\
\hline 2. & Skor rata- & 81,42 & 71,89 \\
\hline
\end{tabular}


1131 Pengaruh Metode Pembelajaran Struktural Analitik Sitentik Terhadap Kemampuan Menulis Permulaan di Sekolah Dasar - Yunita Sari, Ratri Dyah Luvita, Andarini Permata Cahyaningtyas, Vina Iasha, Bramianto Setiawan

DOI: https://doi.org/10.31004/basicedu.v4i4.515

\begin{tabular}{|c|l|c|c|}
\hline & rata & & 13,29533275 \\
\hline 3. & $\begin{array}{l}\text { Simpangan } \\
\text { baku }\end{array}$ & 9,700815435 & 176,62 \\
\hline 4. & Varians & 94,09 & 1,87 \\
\hline 5. & Fhitung & \multicolumn{2}{|c|}{1,87} \\
\hline 6. & Ftabel & \multicolumn{2}{|c|}{1,91} \\
\hline
\end{tabular}

Berdasarkan perhitungan uji homogenitas dua varians, diperoleh data pada kelas eksperimen yang berjumlah 28 siswa mempunyai rata-rata sebesar 8,42; simpangan baku sebesar 9,700815435; sedangkan pada kelas kontrol yang berjumlah 28 siswa diperoleh rata-rata71,89; simpangan baku 13,29533275; varian terbesarnya adalah 94,09 dan varian terkecilnya 176,62. Diperoleh fhitung sebesar 1,87 dan ftabel 1,9 dan tarif signifikan 5\%. Kriteria ujinya jika fhitung < ftabel maka Ho diterima (varian homogen) maka diterima. Karena 1,87 lebih kecil dari 1,91, maka dapat disimpulkan bahwa data kemampuan awal kelas eksperimen dan kelas kontrol dapat diartikan bahwa tidak ada perbedaan varians antara kedua kelas.

\section{Uji Hipotesis}

Uji t berpasangan uji ini dilakukan untuk mengetahui perbedaan antara nilai sebelum diberikan perlakuan (pre test) dengan nilai setelah diberikan perlakuan (post test) dengan menggunakan model pembelajaran Struktural Analitik Sitentik (SAS). Untuk kemampuan menulis permulaan di kelas eksperimen diperoleh $\mathrm{t}$ hitung $-15,45$ dan $t$ tabel 2,0518 dengan kriteria $t$ hitung $\leq-\mathrm{t}$ tabel maka Ho diterima diperoleh hasil $15.452>-2,0518$ maka Ha diterima. Sedangkan untuk kemampuan menulis permulaan di kelas kontrol diperoleh t hitung $-4,16$ dan dan $t$ tabel
2,0518 dengan kriteria $t$ hitung $\leq-t$ tabel maka Ho diterima, diperoleh hasil -4,16>-2,0518 maka ha diterima.

Uji beda rata-rata menggunakan statistik parametris dilakukan untuk data yang berdistribusi normal. Uji beda rata-rata dilakukan untuk mengetahui rata-rata hasil kemampuan menulis permulaan model Struktural Analitik Sitentik lebih efektif daripada rata-rata kemampuan menulis permulaan menggunakan model pembelajaran konvensional. Pengujian ini, menggunakan uji t dua pihak. Berdasarkan perhitungan uji kesamaan dua rata-rata kemampuan menulis permulaan diperoleh thitung 3.065 dan t tabel 2.0211. dengan kriteria pengujian yang berlaku adalah Ho diterima jika $-\mathrm{t}$ tabel $\leq \mathrm{t}$ hitung $\leq \mathrm{t}$ tabel karena perolehan nilai t hitung 3.065 berada pada area penolakan Ho yaitu $-2.0211 \leq 3.065 \geq 2.0211$ maka Ho ditolak dan Ha diterima yang dapat disimpulkan data hasil tes menunjukkan ada pengaruh metode struktural analitik sitentik terhadap kemampuan menulis permulaan yang artinya rata-rata kemampuan menulis permulaan model pembelajaran Struktural Analitik Sitentik lebih efektif daripada rata-rata kemampuan menulis permulaan menggunakan model pembelajaran konvensional.

Hasil penelitian yang diperoleh, memperkuat penelitian sebelumnya yang dilakukan oleh I Putu Suarmei Artana, dkk (2014), menyatakan bahwa ada pengaruh keterampilan membaca dan menulis siswa belajar menggunakan metode Struktural Analitik Sitentik (SAS). Seperti yang dikemukakan oleh Hairuddin, dkk.(2007: 2.29-2.30) metode pembelajaran SAS merupakan salah satu jenis metode yang sangat baik 
1132 Pengaruh Metode Pembelajaran Struktural Analitik Sitentik Terhadap Kemampuan Menulis Permulaan di Sekolah Dasar - Yunita Sari, Ratri Dyah Luvita, Andarini Permata Cahyaningtyas, Vina Iasha, Bramianto Setiawan

DOI: https://doi.org/10.31004/basicedu.v4i4.515

digunakan untuk proses pembelajaran membaca menulis permulaanbagi siswa pemula yaitu kelas rendah.

\section{SIMPULAN}

Berdasarkan hasil penelitian uji $\mathrm{t}$ berpasangan uji ini dilakukan untuk kemampuan menulis permulaan di kelas eksperimen diperoleh $\mathrm{t}$ hitung -15,45 dan $\mathrm{t}$ tabel 2,0518 dengan kriteria $\mathrm{t}$ hitung $\leq$-t tabel maka Ho diterima diperoleh hasil $15.452>-2,0518$ maka Ha diterima. Sedangkan untuk kemampuan menulis permulaan di kelas kontrol diperoleh $\mathrm{t}$ hitung $-4,16$ dan dan $\mathrm{t}$ tabel 2,0518 dengan kriteria $t$ hitung $\leq-\mathrm{t}$ tabel maka Ho diterima, diperoleh hasil -4,16>-2,0518 maka ha diterima. Uji beda rata-rata menggunakan statistik parametris dilakukan untuk data yang berdistribusi normal pengujian ini, menggunakan uji t dua pihak diperoleh $t$ hitung 3.065 dan $t$ tabel 2.0211. dengan kriteria pengujian yang berlaku adalah Ho diterima jika $-\mathrm{t}$ tabel $\leq \mathrm{t}$ hitung $\leq \mathrm{t}$ tabel karena perolehan nilai t hitung 3.065 berada pada area penolakan Ho yaitu $-2.0211 \leq 3.065 \geq 2.0211$ maka Ho ditolak dan Ha diterima yang dapat disimpulkan data hasil tes menunjukkan ada pengaruh metode Struktural Analitik Sitentik terhadap kemampuan menulis permulaan yang artinya rata-rata kemampuan menulis permulaan model pembelajaran Struktural Analitik Sitentik lebih efektif daripada rata-rata kemampuan menulis permulaan menggunakan model pembelajaran konvensional.

\section{DAFTAR PUSTAKA}

Goux, D., Gurgand, M., and Maurin, E. (2017). Reading enjoyment and reading skills: Lessons from an experiment with first grade children. Labour Economics Journal, Vol 45. https://doi.org/doi: 10.1016/j.labeco.2016.09.007.

Hartati, T., \& Y, C. (2015). Pendidikan Bahasa dan Sastra Indonesia di Sekolah Dasar Kelas Rendah. Bandung: UPI PRESS.

Masrup, M. (2012). Keefektifan Pembelajaran Menulis Permulaan dengan Metode Menabung Kata dan Metode Selusur (VAKT) pada Siswa Sekolah Dasar. Jurnal Pendidikan Bahasa Dan Sastra Indonesia, Vol I.

MS, Z. (2014). Pendekatan Kontekstual Dalam Pembelajaran Menulis Di Sekolah Dasar. Mimbar Sekolah Dasar, Vol 1.

Mustikowati, D. (2016). Meningkatkan Semangat Membaca Dan Menulis Siswa Sekolah Dasar Dengan Permainan Kata Bersambut. Jurnal Riset Dan Konseptual, Vol 1.

Suparno, \& Yunus, M. (2009). Keterampilan Dasar Menulis. Jakarta: Universitas Terbuka.

Tarigan, H. G. (2008). Menulis Sebagai Suatu Keterampilan Berbahasa. Bandung: Angkasa.

Temur, T. (2011). Description of Primary Education 1stGrade Students' Forms of Holding a Pencil as well as Their Grip and Compression Strengths. : Theory \& Practice. Jurnal Educational Sciences Turkey Dumlupinar University, Vol 11.

Widyaningrum, H. K., Hasanudin, C. (2019). Kajian Kesulitan Belajar Membaca Menulis Permulaan (MMP) di Sekolah Dasar. Jurnal Pendidikan, Vol 2. 